CATALAN REVIEW

Catalan Review

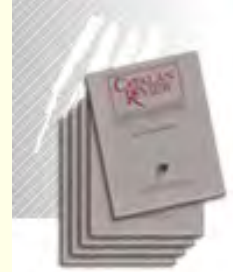

You are accessing the Digital Archive of the Catalan Review Journal.

By accessing and/or using this Digital Archive, you accept and agree to abide by the Terms and Conditions of Use available at http://www.nacs-

catalanstudies.org/catalan review.html

Catalan Review is the premier international scholarly journal devoted to all aspects of Catalan culture. By Catalan culture is understood all manifestations of intellectual and artistic life produced in the Catalan language or in the geographical areas where Catalan is spoken. Catalan Review has been in publication since 1986 .
NORTH

AMERICAN

CATALAN

SOCIETY
Esteu accedint a l'Arxiu Digital del Catalan Review

A l' accedir i / o utilitzar aquest Arxiu Digital, vostè accepta i es compromet a complir els termes i condicions d'ús disponibles a http://www.nacs-

catalanstudies.org/catalan review.html

Catalan Review és la primera revista internacional dedicada a tots els aspectes de la cultura catalana. Per la cultura catalana s'entén totes les manifestacions de la vida intel lectual i artística produïda en llengua catalana o en les zones geogràfiques on es parla català. Catalan Review es publica des de 1986.

\title{
The Moving Mountain: Aporias of Nineteenth-century Catalan 1deology
}

Josep-Miquel Sobrer

Catalan Review, Vol. XIV, number 1-2, (2000), p. 173-193 


\title{
THE MOVING MOUNTAIN: \\ APORIAS OF NINETEENTH-CENTURY \\ CATALAN IDEOLOGY
}

JOSEP-MIQUEL SOBRER

\begin{abstract}
As I begin to write this, a group of astronauts circle the earth aboard the spaceship Endeavour with the intention of drawing a definitive map of our planet. The orbiting craft might be an apt metaphor for my reflections on modern Catalan culture as I try, as it were, to take overhead views and piece them together into a map despite some skepticism as to the definitiveness of my results. I am concerned with open questions, such as what the relationship between consciousness and culture may be, or what the perceivable blocks of culture are and what bearing they have on ideas of nation. While these issues run the risk of transforming themselves into undemonstrable generalizations, I do not think even the study of a limited area such as modern Catalan culture can really make sense without some attention to them. In what follows I try to point out the persistence of certain contradictions or, more precisely, aporias, cultural products that tend towards myth without becomes out-and-out myths. Modern critical discourse has drifted away from the certainties (however misty) of myth. ${ }^{\mathrm{I}}$ The unique political destiny of Catalonia lends its aporetic qualities to Catalan cultural artefacts. The recognition of aporias will be the first approximation to my subject.

Aporia, from the Greek 'a póros (= no passage), implies being at a loss about where one is, or where to begin, or how to proceed. It is an apt term for modern Catalan culture, at least in so far as there is a modern Catalan culture, that is, in so far as there was, beginning in the I830s, a true Renaixença, a recreation of a culture to fit in with contemporary realities. These realities had become tied to questions of nation. So the Catalan re-birth was to be a reinvention of Catalonia as a nation, even though politically that reality was far from accomplished, ${ }^{2}$ Up to a point the whole Renaixença enterprise was a
\end{abstract}

1 In the classical sense, a myth involves a story; in recent usage, however, it has expanded to mean a symbolic kernel of an explanation for diverse phenomena. Joan Ramon Resina explains: "Las mitologías son sistemas credenciales, marcos de referencia orientados a la dispensación de valores... Lo fundamental de [ellos] es su potencia formativa de una narración, su capacidad para generar una historia ${ }^{\prime \prime}(257)$. This is essentially the meaning I give the term myth here. For an overview of the evolution of mythology see Resina's "Teorín y práctica del mito."

2. My co-editor, Joan Ramon Resina, points out that, etymologically, invention 
bluff, albeit quite successful in longevity and legacy. On the other hand the Catalan Renaixença had to do with a discontinuity. Catalonia, as a conception and as a community, had missed out on the imperialistic consolidation of European powers during the early modern period; as a country, Catalonia had dwindled to being a region if not just a province. By the nineteenth century, the century of steam power and social upheavals, singing the glories of prince or nation - creating a set of national myths - would clearly appear anachronistic if not quixotic. Thus Catalan intellectuals felt a contrary pull: towards the simple charms of myth and away towards the internationalist facts of modern life. They were swirling in an aporia.

It is hard to see in the physical map from Jaume Vicens i Vives's Atlas de bistoria de España (FIGURE I) the clear limits of what today is Catalonia (or Portugal, or Euskadi, for that matter), a fact that might indicate that a nation (a 'cultural artefact' as Benedict Anderson insists) is not created or imagined centripetally, beginning with some naturally established margins and filling in the space with arbitrary monochromaticism, even though this may be the way we taxonomize and store notions of nation in our minds. But then, can we say, conversely, that a nation grows from a focus, that it is created centrifugally as the outgrowth of a concrete seat of power? Clearly we need both poles, center and periphery, in order to create sense.

We cannot attribute an origin to the question of national consciousness without taking into consideration the matter of time, and with this we face other aporias, the mental impasses that constitute the theme of this paper. The importance of place is, paradoxically, a matter of time. Place can be thought of as what remains when all else passes. A belief in place is a result of the feeling of the instalbility of time, the illusion of a protection against change. Place amounts, in our imagination, to non-caducity. The brunt of the work of the Catalan intellectuals in the Renaixença consists in posing Catalonia as a definite, real space, and such posing vertebrates the movement. This mythicizing of place issues from Renaixença notions of history which in turn imply a sense of loss - loss of autonomy - and consequent resentment of that loss. Thus space is time, loss, and resentment; a metaphor transposed into a metonymy. From this metonymic imaging comes an attitude of rejection -Catalonia as not-Spain 3 - which conjures an escape to a lost place, which is really lost time.

derives from invenio, to 'come upon'; Catalans of the Reniaxença came upon the idea of a nation and so they (re)invented Catalonia to fit the national idea.

3. Joan Ramon Resina has posited, conversely, that contemporary Spain's selfconstruction depends on positing Catalonia as Other. See his "Hispanism and its Discontents." 


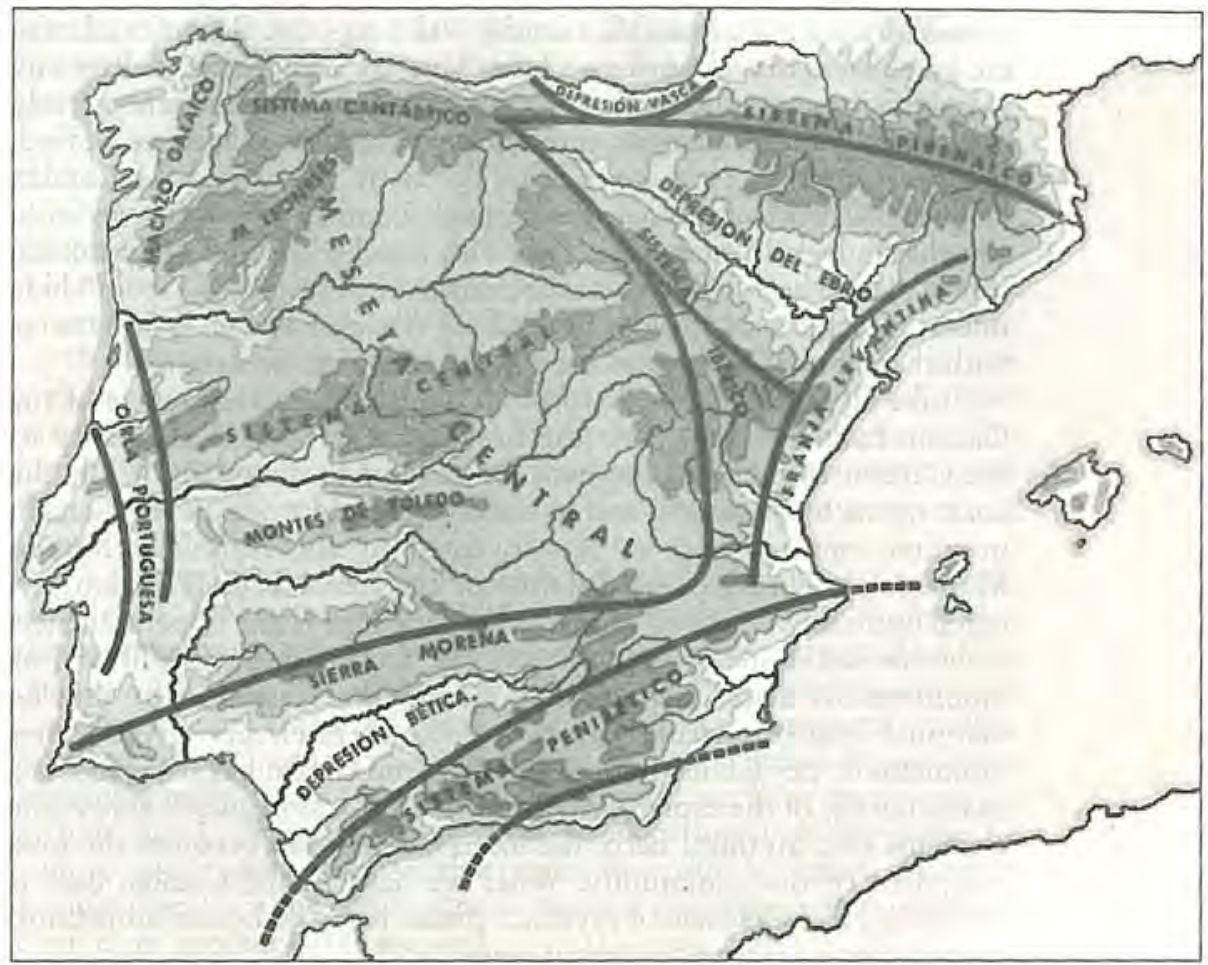

FIG. 1

Catalan literature owes its modern resurgence, at least in part, to ideas of nationalism that originated in such German Romantics as Herder and Schlegel, particularly Herder (Flitter). Their concept of Volksgeist is sufficiently known. Nationalist ideas found fertile ground in the imagination of a number of intellectuals more or less immediately related to the growing bourgeoisie in the city of Barcelona at the time when industrialization and capitalism were developing during the nineteenth century. The idea of a national Catalan literature owes its birth to the internationalist movement of Romanticism: another paradox. The emblematic piece that supposedly opens the modern period of Catalan literature, a short poem by Bonaventura Carles Aribau, "La Pàtria," was written in Madrid; it is a poem created by nostalgia.

The mythmakers of modern Catalonia wanted to create a timeless sense of place. Not easy for the Catalan area, given its entrenched 
administrative divisions (Catalonia, Valencia, the Balearic Islands, etc.), the fact that its borders to the West are not punctuated by any cataclysmic geography, to say nothing of the unregulated and actively persecuted condition of its one unifying element: language. Indeed, because Catalonia is so open, this linguistic frontier - the Catalan language - had to become pre-eminent. Contrast this situation with; say, that in Ireland, and compare it with Israel where the agglutinizing role is played by religion (Glick). Conversely, notions of "Spain" hide under the skirts of geography making "la peninsula" synonymous with the nation, the Portuguese and the rest of us be damned.

Like all mythmakers, Catalan mythmakers took advantage of the Catalan handicap and made the best of the geographical duality of the Catalan landscape: mountain terrain and coastal plain. While the coast opens to the world and to history (the old myth of the Catalan maritime empire, more or less invented by the chronicler Ramon Muntaner, was revived at the time of the Renaixença [Hillgath]), it befell upon the mountain to be the keeper of the flame of permanence, to be the backbone of the country. The duality mountain/littoral or mountain/city also allows for dual marginality. Catalans may thus be marginal both externally (from Spain) and internally (from either mountain or city). Dual marginality, as René Girard has observed, is a characteristic of the expiatory hero of myth; Catalonia itself enjoys the elements of a mythical hero, the loser/winner who becomes the lone coagulant of the community. What we have in the Catalan case is something like a mosaic of mythical pieces ready to be assembled into stories, that is into myths strictu sensu.

One currency Romanticism put in circulation was the appeal of mountain-climbing. Marlon B. Ross explains;

One reason Romantic poets are so obsessed with climbing mountains is that the activity perfectly emblematizes the poet's charge of self quest and world conquest. Mountain climbing and viewing is the ultimate sublime experience; testing the power and limits of self, it stresses the solitude of self-questing and pits the self against nature's power. The height of the mountain represents both the ever-spiraling ascent of imagination and the ever-present threat of falling, the loss of self-identity, the reabsorbtion into nature's overrriding power. It is from mountains that prophets proclaim their truths; for the poet-prophet the mountain symbolizes the necessary solitude of the leaders of men and the necessary stance of truth -its transcendence, its elusiveness, and its immense might. It is another metaphor of masculine potency, which, through association, reinvests the poetic vocation with power and influence. (44)

Ross is thinking primarily of English poets although what he says would explain, for example, much in the poetry of Joan Maragall. England, with its industrial revolution centered in the textile industry, 
was a model that modern Catalonia was seeking to emulate. Influence of English culture on Catalonia would reach its summit at the time of the Pre-Raphaelites (Cerdà). The idea of the mountain as defining foil for the artist was to combine with the mountain as sacred space, as chthonic self.

Nevertheless, during the second half of the XIX century, the country was pouring itself out to its seaboard. If geographically the mountain was the center, demographically the center was the coastal plain and particularly Barcelona. Not surprisingly the Catalan myth mosaic shows an ambivalence towards the mountain, an ambivalence exacerbated by the dubious legacy of the civil wars of the XIX century, the Carlist wars, and by the legacy of bandolerisme. The literary monuments of Catalan mythography show how entrenched this ambivalence is. The history of Catalan literature shows it duration.

A feeling of cultural newness in Catalonia beginning in the fourth decade of the nineteenth century was made into a reality by the contemporary coining of the metaphor Renaixença, re-birth. ${ }^{4}$ The concept of Renaixença might have been more of a packaging ruse than a real artistic movement, as I shall explain. But let us assume the reality, however ethereal, of this mid-nineteenth-century Catalan Renaissance. Etymologically, words derived from néixer, such as (re)naixença, include nació, Without a birth there is no nation; it is literature, or culture - not geography-, that seeks to create a nation. Another paradox here: it is the child - the re-nascent literature - that is to give birth to its mother - the nation.

Still, what is missing from this re-birth, and from all these parturient metaphors, is the mother. Can we have a Renaixença or indeed a nation without a mother? Everything is possible of course in the realm of the imagination, and we know that Athena was born of Zeus. But we still need some sort of mothering, a mother paradoxically - who will be calling our bluff. And so in modern Catalan literature we have a quest for a womb, a quest for a place of gestation. Deprived of patriarchal legitimacy (having lost king and government and endured repeated military and legislative defeats), Catalans searched for a matriarchal justification; denied the autonomous, they looked for the autochthonous. Only when, in 1906, the establishment of Prat de la Riba's Mancomunitat gave Catalans a measure of autonomy could their mythical thinking turn its back on Nature. Before then, la natura, la terra catalana, la muntanya - the feminine - would set the tone in literature and the arts. Wordsworth

4 The term was originally 'renaixement' and it was applied to contemporary cultural activity by Gaietà Vidal i Valenciano in 1864 . See Jorba 26. 
wrote that "the child is the father of the man";5 here the child is or would try to be the parent of the mother. Renaixença is a return (supposedly a return to the perceived glories of the Catalan medieval past, as the rhetoric of the time claimed); the movement is also a congealing of ideas that took hold of the collective imagination in response to social change. The central idea of a sacred earthborn origin was the angle that helped "sell" the movement. Such a resorting to the maternal, to the feminine, itself a manifestation of patriarchalism, would nonetheless be resented at a deeper level in a patriarchal society such as bourgeois Barcelona and it would create a tension that gives. turn-of-the-century Catalan culture its dynamic. This quest for a legitimizing womb is also a quest for power: thus the aporetic condition of the movement which we see beginning with Aribau's emblematic "La Pàtria," in which paradoxically the word for fatherland - for patriarchy - takes on a feminine gender. Basically Aribau's poem is a claim for legitimacy. It shifts from agnatic, or male, principles (with references to the poet's "patró," to history - "aquells forts"-) to enatic, or female, ones (references to "el mugró matern," and indirectly language and the land).

In more general terms, the primary quest of modern Catalan literature is for that place of belonging, for that womb or center which will give a group its nation and a nation its voice. At the same time, and reversing the Oedipal paradigm, the masculinist society that produced these 'cultural artefacts' will show itself mistrustful of the mother figure and, once it has "conquered" it, will appear eager to reject it, for its quest is one for power. This dynamic explains the strength of the pastoral mode in Renaixença literature, since the pastoral -an ideal that also experienced a grand revival during the Romantic period - is at once regressive (back to the primitive splendor of Arcadia, back to the mother) and rejective (of the materialism that inevitably informs daily life, away from the mother). ${ }^{6}$ This tension might well have given the Renaixença its longevity and assured the success of its project: the viability of modern literature in Catalan.

Let us now look at the map the Endeavour astronauts would have drawn had they been up in space one hundred years ago with socially attuned instruments. (Vicens i Vives's map LXXIII, FIGURE 2.) The darker areas represent industrialization. You can see how industrial development extends from, or into, Barcelona like a cancer, following primarily the basin of the Llobregat. Whether this growth follows a male model - a penetration of industrialization into the country - or

5 In his "My heart leaps up" of 1807.

6 Work in progress by Josep-Anton Fernandez makes a case for the self-percerved non-pertinence of Catalans. 1 refer to his presentation at the 2000 MLA. 


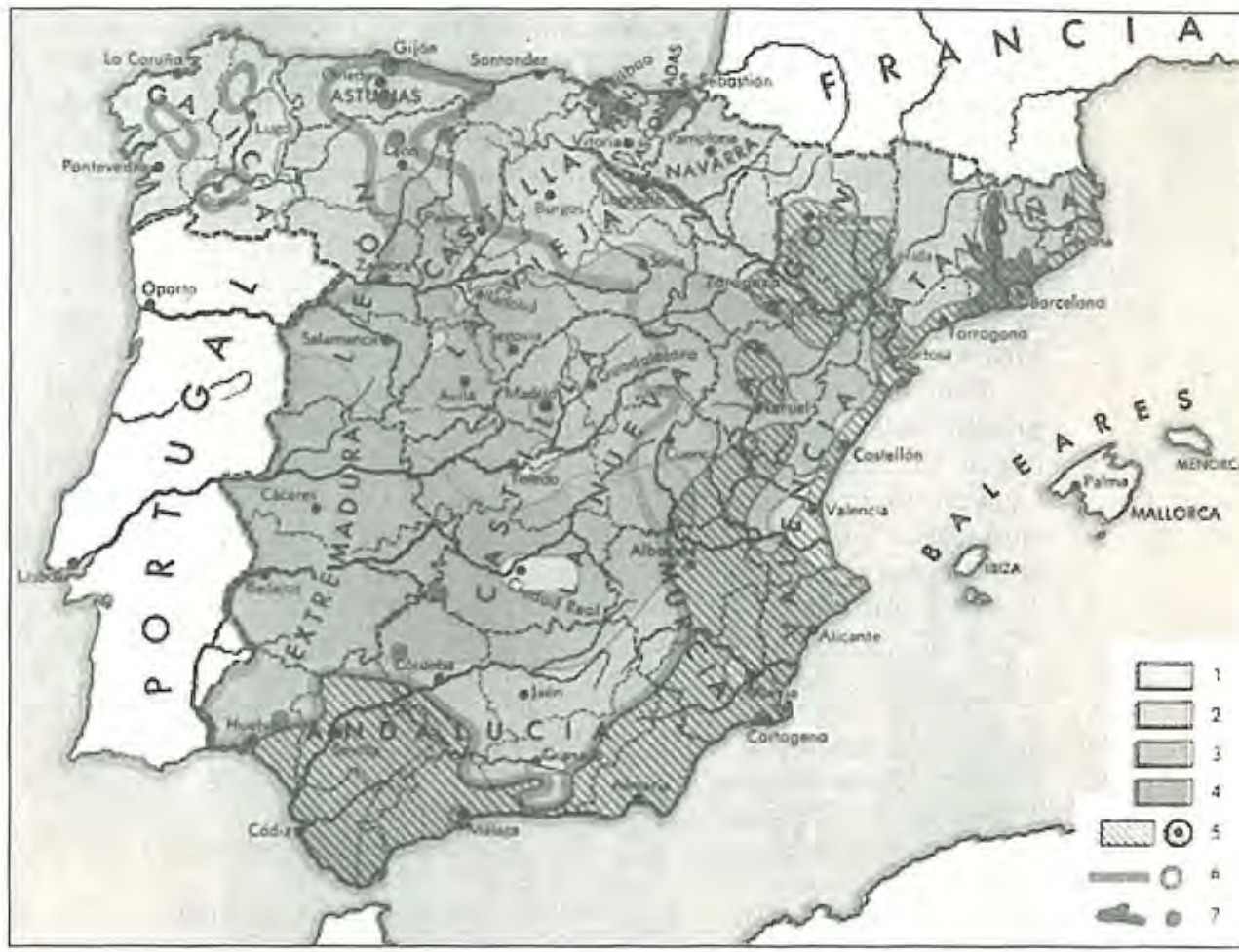

FIG. 2

a female model - an effluvium of energy towards the sea- does not really matter. What is clear is that we see here the dynamic that consciously or not informs modern Catalan thought and imagery: the aporetic antagonism between city and country, between "man" and "nature", between nomos and physis, between Barcelona and the main image for the natural: the muntanya, not so much a concrete mountain but a mountain world, the wilderness. We have here the opposition city/country that tends to surface in societies undergoing a process of rapid economic growth. Will the city go to the mountain to seek its origins and find its purity, or will the mountain descend to the city to redeem it?

If there is a central motif in modern Catalan literature, it is this aporia. Literary and cultural expressions of the last I5O years or so abound in examples, all the way up at least to Noucentisme. I shall mention later other cases -Verdaguer's Canigó, or Guimerà's Terra 
baixa-; first I will discuss less famous but equally significant cases. The reader should bear in mind that, beside the literary works I will quote, three grand Catalan cultural projects revolve around the aporia I am describing: One is the adventure of excursionisme and the far-flung search for mountain folk-lore; another is the recreation in Barcelona's Museu d'Art de Catalunya of the sacred spaces of Romanesque painting from the mountains (Meisler), the third is Antoni Gaudís plan to rebuild the mountain as a church devoted to the Holy Family in the middle of the modern, expanding city. FIGURE 3.

But this dynamic is alos at work in not-so-monumental productions. Let us see two examples. Inr839, Joaquim Rubió i Ors began to publish in the Diario de Barcelona a series of poems in Catalan which he gathered in $184 \mathrm{I}$ under the title he had used for his signature: Lo Gayter del Llobregat. This collection, and its eponymous opener, expands the autochthonous quest of the "oda" $\mathrm{La}$ Patria continuing Aribau's incipient pastoralism.7 Rubió's six "Gayter" stanzas in his opening poem reiterate the same idea, often in the form of a rhetorical question. Here is the first one:

Si't donás la sua corona Un rey y'l ceptre de plata, $Y$ son mantell d'escarlata, $Y$ son trono enjoiellat,

¿Pera esser rey deixarias

Tas baladas amorosas, Ni tas montanyas frondosas, Ni ton joyós Llobregat? (Rubiö I)
If a king offered you his crown and his silver scepter, his purple cloak, and bejeweled throne;

would you - to be king give up your love ballads, your forested mountains, or your joyous Llobregat?

The insistent tone of the poem makes the answer obvious: the beauty of the mountains, and the freedom to practice poetry thereupon, are preferable to the best-appointed royal sinecure. Ecologically speaking, the Llobregat river of 160 years ago might have offered a less lamentable sight than it does today, but still the summons to a life of parsimonious songsterism should have seemed as comical in mid-r $9^{\text {th }}$-century Barcelona as, say, Don Quixote's giddy address to the cabreros of La Mancha. But it didn't. Rubiós message, by opposing a natural paradise to be regained to an orientalist pipe-dream,

7 Rubió himself claimed to have created the Renixença movement (Jorba 23). Curiously the most direct model for Rubiós utopia is the poetry of seventeenth-century poet Francesc Fontanella, who situated his Garcilaso-like Arcadia on the shores of the two Barcelona rivers, the Llobregat and the Besós. 


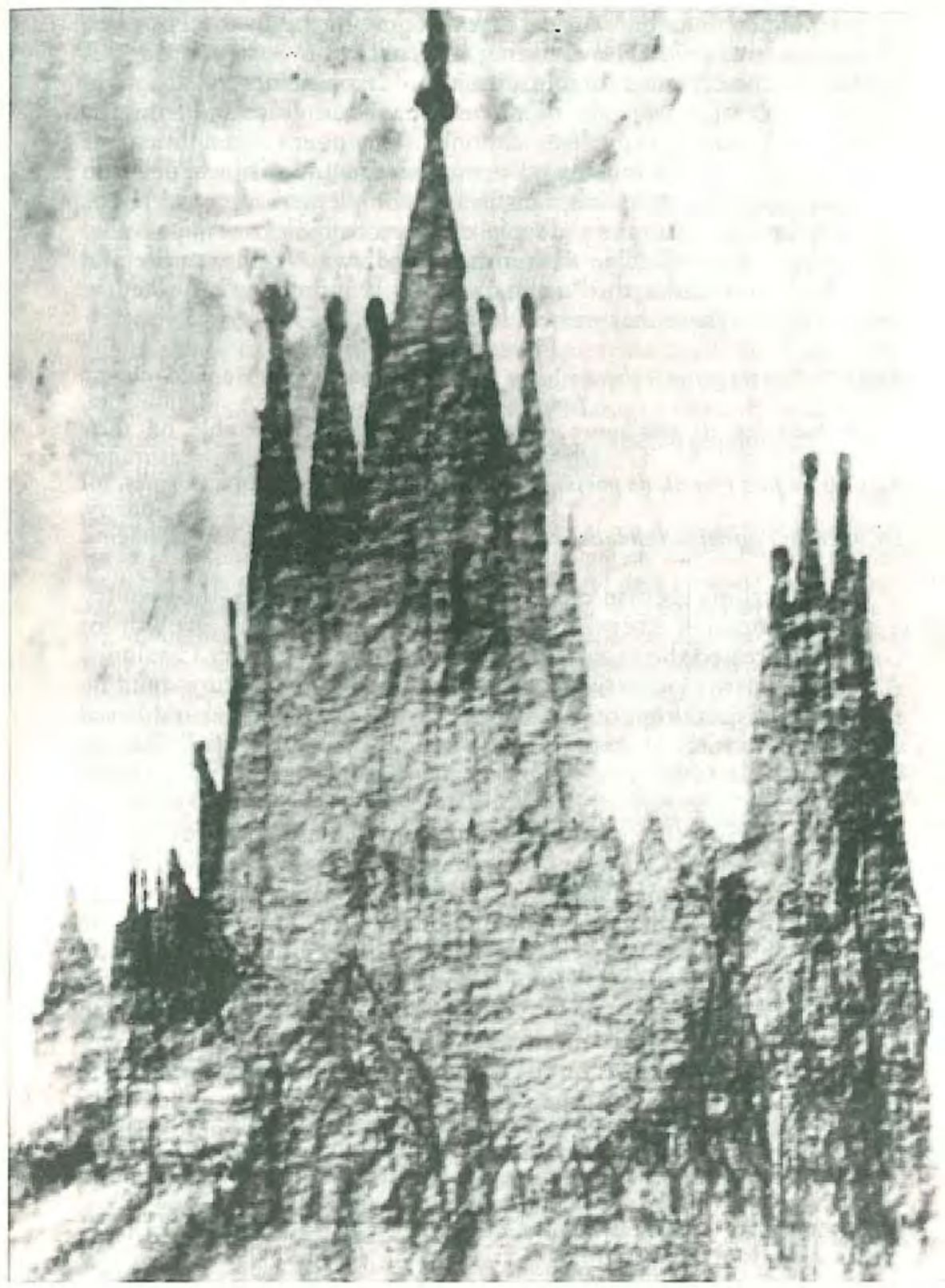

FIG. 3 
was making an unambiguous defense not only of the pastoral but alsoof the mode of refusal. By writing in Catalan he was centering his message in the mythical double alienation I have mentioned above, in this case alienation from the dominant, Spanish, culture and from the dominant, Catalan, capitalist economy. The poem exemplifies the coupling of literary idealism and a negativist attitude, it presents both call and rejection, two antagonistic but complementary movements that help in the creation of the social concept. Rubió's basic idea is that the essence of the Catalan nation has ebbed away from city life and must be found under the "calbo front de la muntanya" (quoted in Jorba 114$)$. It is there that we will find

Records d'uns comtes soberans que [un dia Feren tremolar els reis sobre llurs [tronos;

Records de Jocs Florals, de poesia, The memory of sovereign counts [who, once, made the kings tremble on their [thrones; De guerres, itorneigs, $i$ cavallers. ${ }^{8}$ [poetry, of wars, and tourneys, and of knights.

As Barcelona grew in crowds and in social problems, the country -the mountain- grew in its romantic appeal. The growth of Barcelona created the macrocephalic nature of present-day Catalonia. A similar polarity occurred in contemporary Basque culture dividing the Euskera-speaking countryside from the Castilianized industrial cities, the former of course representing the "authentic" Basque (Christian). In Catalonia, soon after the first bleat of Rubió's gayta, ${ }^{9}$ a plan for the enlargement of the city - today's Eixample - had been approved (in I858), implemented, and had entered its process of growth and adulteration. Contemporary Barcelona was as antipodal to Arcadia as can be imagined. Conservative Catalanism, being by and large a Barcelona phenomenon, hid behind the utopianism of the barely updated pastorals of its intellectuals. A political phenomenon fed by, and feeding, the powerful Barcelona bourgeoisie of merchants -or robber barons - such as Antonio López and industrialists such as Eusebi Güell, relied on the symbolism of the wilderness and organized its mythologies on the dynamic of city-country opposition. Only in the $20^{\text {th }}$ century some intellectuals, Eugeni d'Ors and Antoni Gaudi principally, aided by writings of Joan Maragall, would seek to

8 Lo Gayter del Llobregat, vol. I. 70. The modern Catalan Jocs Florals were inaugurated in 1859 .

9 Though bagpipe-like instruments exist in Catalan folk music, Rubió, a city dweller preferred the rather unpopular Spanish cognate gayta over more usual Catalan names for such instruments as xeremia or sac de gemecs. 
transcend that opposition. To the medievalism that the influence of the German Romantics fostered in nineteenth-century Spanish letters, we must add the more particularly Catalan dimension of pastoralism - of mountain idealization - fostered by the demographics of the industrialized economy.

The idealization of the country was alive and fecund when in 1903 Joan Maragall addressed the Ateneu Barcelonès with a season-opening speech that has become one of his most famous texts. The podium was the same as had served Angel Guimerà eight years prior to orate publicly in Catalan (it was the first address by a president of the Ateneu to be delivered in Catalan, one of the first instances of public speech in the language in modern times), a coincidence Maragall remarked in his own speech. Maragall's address was published as an essay titled "Elogi de la paraula." This essay presents what Maragall termed "teoria de la paraula viva" and to illustrate this notion, Maragall explains that once, lost in the wilds, he encountered a shepherd:

I l'home, que era com de pedra, girà els ulls en el seu rostre extàtic, alçà lentament el braç signant una vaga drecera, i mogué els. Ilavis. En l'atronadora maror del vent que engolia tota veu, suraven sol dues paraules que el pastor repetia tossudament: "Aquella canal...", $i$ signava enlla vagament cap amunt de les muntanyes. "Aquella canal..": ique eren belles les dues paraules entre el vent gravement dites! i Que plenes de sentit, de poesia! (Maragall 665)

And the man, who seemed made of stone, turned his eyes in his ecstatic face, raised his arm slowly pointing to a vague shortcut, and moved his lips. Within the deafening rumble of the wind that was engulfing all voices, two single words were floating, words that the shepherd would stubbornly repeat: "That gulch...", and he signaled forward, in a vague manner, towards the mountains. "That gulch..." : how beautiful those two words uttered gravely in the wind! How full of sense, of poetry!

Maragall seems blithely oblivious that to a lost hiker any words of guidance would appear beautiful; so might a gas station appear to a lost traveler as the most welcomed sight. Responding to Maragall's fuzzy logic, critics have had a field day pointing out the weaknesses and contradictions of the "Elogi." Joan Lluís Marfany, for example, remarks:

com a teoria, la de la paraula viva no s'aguanta dreta: és d'un subjectivisme tan absolut que li lleva radicalment i d'entrada allò que tota teoria ba de tenix, valua general que la faci aplicable a tots els casos concrets. Res no ho il.lustra millor que els absurds exemples escollits per Maragall. (224)

As theory, Maragall's "living word" cannot stand its ground. To begin with, its absolute subjectivism radically deprives it of what any theory must have: a general value that will make it applicable to all concrete cases. Nothing illustrates this better than the absurd examples Maragall chose. 
Indeed. But how could an intelligent man like Maragall be drawn to such blather? It can only be because at the time the idealization of the mountain, and the mode of refusal, had become accepted, had become an ambient myth.

Deafened by critical skepticism, two important, even essential, elements of the "Elogi" have escaped attention: the religious and the pastoral. Maragall's "theory" of the "living word" claims that, through overuse and interestedness, our language has lost its poetic and sacred dimension and that this dimension can be found in the mouths of the pure -children, shepherds - rather than in the exchanges of economists, politicians, even (I fear) academics. The "Elogi" bears a startling resemblance to the opening chapter of Jacques Derrida's Of Grammatology, where the guru of deconstruction distinguishes between grammatological and pneumatological writing (Derrida 17), the Elogi being an example of the latter.

If we look at the speech's underlying imagery we see Maragall's constant resort to religious language: glòria; la meravella espiritual de la Naturalesa; la paraula es féu carn; llum d'inspiració. . Ilum infinita; la santedat de la paraula; transportat a la divina esfera; vindrà el regne llur; la paraula com cosa sagrada, inviolable; el diví misteri de l'ésser $i$ del devenir... [... glory; the spiritual wonder of Nature; the word was made flesh; light of inspiration ... infinite light; the sanctity of the word; transported to the divine sphere; their kingdom will come; the word as a sacred, inviolate thing; the divine mystery of being and of becoming...] and so on and so forth. The whole essay is relentlessly oracular - or if you wish pneumatological. Maragall was not producing a theory but rather preaching a sermon the religious language of which would consolidate his authority. The sermon was a transformation of the mode of refusal we saw in the Gayter. It was now Maragall's turn to say No, to reject bourgeois life as something broken off from the alma mater of its mountain origins, and to turn towards the windswept pristine essence of the mountain. In short, Maragall painted a mythical backdrop. A quest for the collective healing and purity had to be achieved through expiation, through some sacrifice, through the elimination of an appropriate scapegoat. As in Rubió, Maragall's scapegoat is intanglible (defiled language) and metaphoric (modern life). Paradoxically, it was the "savior" - the mountain, the shepherd, wilderness, the natural world - that was being sacrificed as contemporary economic conditions were deruralizing Catalonia and creating a life of apparent ease within the polluted city characteristic of the modern world.

It seems to be one of the uses of literature to grant our imaginations the illusion of radical alternatives. As life becomes complicated with labor conditions and financial restraints we dream of 
freedom and open-air adventure. Such fantasies, I suspect, actually strengthen the status quo. In any case, Maragall's "Elogi" is fraught with political dimensions as its author directly links Catalanism to his religious ideal: "La nostra causa no és sols la causa d'una nacionalitat, no és un plet d'Estats o una renyina de famílies, sinó un ideal humà arrelat en l'amor diví que anima bellament al món" (667). [Our cause is not only the cause of a nationality; it is not a quarrel among States or a family feud, it is rather a human ideal with its roots in the divine love that beautifully animates the world.] Unaware that the referentiality of language - its différance - has no end, Maragall (who here 'departs' from Derrida) thinks he knows the way to his divine Llobregat, to his terra alta, to his holy mountain. And the way there, as with his colleagues and predecessors, begins by a refusal -in this case in language - of the materialistic. To the contradiction, of which Maragall showed some awareness in the way he ended his speech, that discursive language is used to explain the superiority of the poetic we must add the contradiction that the Nietzschean Úbermenschen Maragall proposed as his new heroes inspired him towards the language of religion and confirmed him in his obedient Catholicism.

With his agitated "Elogi," Maragall was surely lamenting a loss: that of the sacredness of poetry. Having read and translated Nietzsche, and having admired Nietzsche's assumption of a sacral tone in his Zarathustra, Maragall (who had published his translation of fragments from Also spracht Zarathustra in 1893) could not ignore that also in Nietzsche God had been pronounced dead. ${ }^{10}$ Yet Maragall clings both to Nietzsche and Christianity, just as Guimerà strove to marry Anarchism with the Christian Gospels in his most famous play, Terra baixa (Sobrer). The contradiction between Maragall's modernisme and his religious convictions would channel his work towards a new synthesis. Those contradictions, clear though they may appear to today's readers of the "Elogi," are heirs to the ideological setup of Renaixença thinking. Such ideology (and I am referring to the general way Catalan intellectuals from Rubió to Maragall tended to organize their imagination) went undetected as such because it fed on a literary tradition that relied on a mode of rejection as the examples above illustrate.

Present-day Catalonia is awash in mentions of nationhood. There is hardly a publicly funded cultural enterprise - museum, theater, bibliography - that is not termed national. It does not take a Pepe Carvalho to see in this the expression of an unrealized wish. What

Io Nietzsche's loathing of Christianity did not escape Maragall's contemporary Pompeyo (or Pompeu) Gener (Sobejano 42). On Gener and other Catalan modernista Nierzscheans see also Epps "The (In)Effectual Intellectual." 
prompts this disquisition is not the question whether Catalonia is or is not a nation. The question to pose is rather whether, as a group, Catalans believe in their nationhood, and whether this belief is congruent with their collective and individual dispositions. Perhaps the myth that congealed the communal sense of place ca. 1850 , explain such lasting irresolution. The presentation of a sense of place came accompanied with an attitude of refusal: the myth of Arcadia was to marry the myth of expiation. Catalonia had to find its place and be denied it; it had to establish its Eden and be expelled from it.

To explain this I must refer to cases in which the mode of refusal turned against pastoralism, cases where the aporia of the mountain breaks down, that is, seeks its resolution in a movement towards expiation. In Verdaguer's epic poem Canigó the mountain is a place of origin, but a place that has to be abandoned. Its protagonist, Gentil, fails to fulfill his human or Catalan destiny because he chooses to linger amid the fairies and oreads of mount Canigó and shuns the battlefield; he nevertheless dies at the hands of the seductive nymphs. Opting for the feminine gifts of the "rei moro" over his stark Llobregat of masculine war-bonding, Gentil is rejected by the emergent Catalan nation imagined by Verdaguer. Gentil's choice is between his desire and his taboo-sanctioned duty as a Catalan man; in choosing his desire - as Freud would predict, or as Bécquer- he meets his doom.

In Guimerà's Terra baixa, the protagonists resolve their conflict (morality vs. legality) by fleeing to higher ground, but their mountainbound solution is fraught with uncertainty and danger. Guimerà's play stands between the Renaixença model of the sanctity of the mountain and the modernista model which casts a critical eye on the whole idea. Modernista writers were to react to the Holy Mountain model, and react with a vengeance. Indeed they appear stuck in the mode of expiation to the point of morbidity. Brad Epps has studied the abundance of cadavers and of the idea of decay in modernista fictions; I refer my readers to his illuminating essay, "The Cadaver of Progress," for further detail and for Epps's lucid commentary. Thanks to his work, I need give here only the briefest examples. The modernistes, Raimon Casellas and Caterina Albert, in their best known novels, saw in mountain life also a primitive, hostile world that had to be abandoned. Caterina Albert's Solitud, which she published under her masculine persona, "Víctor Català," suggests that the mountain, in that it is unplowable and thus impenetrable terrain, represents the masculine aspect of the chthonic, out to control and rape the female protagonist. Contrarily, for Casellas, the mountain finds its expression in the overfeminized, and infernal, character of $\mathrm{La}$ Roda-Soques, a mountain-goat of a whore. A failure to inseminate the 
mountain (by Christianizing and educating the mountainfolk) - while the mountain men busy themself inseminating La Roda-Soqueshinges the action in Casellas's Els sots feréstecs. For these modernistes, and for others, the aporia becomes even more heated. There is no place to go to, only a place to reject. Solitud's Mila ends the novel by moving away towards no possible destination, a more radical ending than Guimerà's idealistic final thrust.

The mountain was doomed to fail as the mythical space that would create a definitive sense of origin. Posing the mountain as alma mater was an anachronistic project to begin with (see figure 2), a compensation for the upheavals of change, of massive population shifts, and of general pollution of the environment. But the 'myth' of the mountain succeeded in some ways. The noucentistes attempted to solve the paradox by 'civilizing' the mountain, by having architecture arbitrate it and human energy enslave it, as Eugeni d'Ors demanded in 1907; other noucentistes would bring the mountain to the city. Think of Guerau de Liost's La muntanya d'ametistes, a book he followed with La ciutat d'ivori, or of J. V. Foix's poetry with the emblematic line: "És per la Ment que se m'obre Natura" [It is through my mind that nature opens up to me]. In a 1927 interview with Tomàs Garcés, Guerau de Liost explains the intention of his book: "un alçament contra el ruralisme a l'ús" [an uprising against the dominant ruralism] (Garcés 27), which is surely a reference to such modernistes as Victor Català and Casellas. In the same piece Guerau blasts those for whom "l'udol era la màxima troballa" [the scream was their greatest artistic find] (perhaps a reference to Maragall's "paraula viva"): "contra aquest ruralisme indigne calia adreçar una ironia benèvola que l'atuís a poc a poc" (Garcés 27) [against such debased ruralism we needed to erect our benevolent irony and so gradually bring it to an end]. The charge against ruralism was one of the banners in Eugeni D'Ors's noucentista program. Was it a stylisic reaction, as Guerau's mention of "benevolent irony" suggests? Or was it that there could be no place for aporia in the noucentista program?

Indeed Ors called for bringing his arbitrarisme to the mountain, for moving the mountain out of the way. Contrarily, Antoni Gaudi's Sagrada Família can be seen as an attempt to build a mountain in the middle of Barcelona so that he could bring home the mountain the prophet would not go to. If the bourgeois economy had expelled people from their mountains (Balcells, Noyes), the bourgeois architect would rebuild it in their new home. Gaudi devoted the last part of his life to this project, which was to be one of redemption; or if we think of the mountain as phallic - and every building is literally an erection-, one of domination and insemination; the Sagrada Familia, like the word patria, is ambisexual. If the industrialized megalopolis 
would not go to the mountain (modernista protagonists, as we have seen, were fleeing their aeries), the mountain would come to the city to give it its bosom, its center, its wholeness, its Holy Family: the Sagrada Familia. Catalonia's rebirth would then have been arbitrated into control."

JOSEP-MIQUEL SOBRER INDIANA UNIVERSITY

\section{WORKS CITED}

AlBERT, Caterina ("Víctor Català"). Solitud. Barcelona: Joventut, 1905. ANDERSON, Benedict. Imagined Communities. London: Verso, 1983. ARIBAU, Bonaventura Carles. "La pàtria. Trobes." El Vapor 68 (1833): 3-4.

BalCells, Albert. Història dels Paìsos Catalans. Vol. 3. Barcelona: Edhasa, 1980.

BarTHES, Roland. Mythologies. Annette Lavers, trans. New York: Hill \& Wang, 1972.

Bofill I MATES, Jaume ("Guerau de Liost"). La muntanya d'ametistes. Barcelona, 1908.

-. La ciutat d'ivori. Barcelona, 1927.

CASELLAS, Raimon. Els sots feréstecs. Barcelona, I90I.

CERDA I SURrocA, Maria Ãngela. Els pre-rafaelites a Catalunya. Barcelona: Curial, ig8I.

Christian, William A. Introduction to his Visionaries; The Spanish Republic and the Reign of Christ. Berkeley: U of California Press, I996.

DERRIDA, Jacques. Of Grammatology. Tr. Gayatri Chakravorty Spivak. Baltimore/London: Johns Hopkins UP, 1974.

Epps, Brad. "The Cadaver of Progress: Death and Putrefaction in the Modernist Catalan Novel." Forthcoming in Silvia Bermúdez and Antonio Cortijo, eds. Multilingual Spain. University of Delaware Press.

"The (In)Effecual Intellectual: Of Nationalists, Modernists, and Catalunya." Forthcoming in Teresa Vilarós, ed. Brokering Spanish Postnationalist Culture.

II My indebtedness to Joan Ramon Resina and to Brad Epps should be apparent to the readers of this paper. Resina furthermore commented incisively on an early draft. 
FERnÁNDEZ, Josep-Anton, "'Nosaltres no som d'eixe món': The Living Dead of the Periphery; or, The Catalans as Monsters." Catalonia forum II. MLA Convention. Washington Hilton Hotel. Washington, D.C. 30 December 2000.

FlitTer, Derek. Spanish Romantic Literary Theory and Criticism. Cambridge (UK): Cambridge UP, 1992.

Foix, J. V. Sol, i de dol. Barcelona: L'amic de les Arts, 1947.

GARCÉS, Tomàs. "Conversa amb Bofill i Mates". Revista de Catalunya $6(1927): 25-53$.

GIRARD, René. El chivo expiatorio. Joaquín Jordà, trans. Barcelona: Anagrama, 1986.

GlicK, Thomas F. "Catalans as Jews: Catalan Philosemitism in the Franco Era" in Salvador Espriu, La pell de brau. Marlboro, V'T: The Marlboro Press, 1987.

Hillgarti, J. N. The Problem of a Catalan mediterranean Empire. 1229-1327. London: Longman, 1975. Catalan translation: El problema d'un imperi mediterrani català. 1229-1327. Trans. J. M. Sobrer. Palma de Mallorca: Moll, 1984.

JorBA, Manuel. "El romanticisme" in Riquer, Comas, Molas, eds. Història de la literatura catalana. Vol. 7, 77-122. Barcelona: Ariel, I986.

MarfanY, Joan Lluís. "El modernisme" in Riquer, Comas, Molas, eds. Història de la literatura catalana. Vol, 8, 75-186. Barcelona: Ariel, I986.

MeISLeR, Stanley. "The Case of the disappearing frescoes." Smithsonian 29 (1998), 53-60.

NOYES, Dorothy. "Breaking the social contract; violence and production in the catalan mountains at the turn of the century." Published in this issue.

NúÑEZ SEIXAS, Xosé M. "El mito del nacionalismo irlandés y su influencia en los nacionalismos gallego, vasco y catalán (18801936)." Spagna contemporanea 2 (1992): 25-58.

ORs, Eugeni d'. "L'arranjament de les muntanyes." [is May 1907] Glosari. Ed. Josep Murgades. Barcelona: Edicions 62, 1982.

ResinA, Joan Ramon. "Hispanism and its Discontents." TwentiethCentury/Siglo XX I4 (1996): 85-135.

"Teoría y práctica del mito." Mythopoesis: literatura, totalidad, ideología. Ed. Joan Ramon Resina. Barcelona: Anthropos, 1992. 736.

"El dilema de la modernidad: ¿Historia o mito?" Mytbopoesis: literatura, totalidad, ideologia. Ed. Joan Ramon Resina. Barcelona: Anthropos,1992. 25I-279.

Ross, Marlon B. "Romantic Quest and Conquest; Troping Masculine Power in the Crisis of Poetic Identity." Romanticism and 
Feminism. Ed. Anne K. Mellor. Bloomington and Indianapolis: Indiana UP, 1988.

RuBIó i ORS, Joaquim. Lo gayter del Llobregat. Barcelona: 184r. Sobejano, Gonzalo, Nietzsche en España. Madrid: Gredos, 1967.

SOBRER, Josep Miquel. "Man and Beast: The Nietzschean Heroics of Àngel Guimerà's Terra Baixa". Romance Quarterly 46 (1999): 196203.

VICENS I VIVES, Jaune. Atlas de historia de España. $8^{\text {th }}$ ed. Barcelona: Teide, 1973 . 


\section{NOTE}

We are printing in this issue corrected versions of five maps that, through no fault of the author or the editorial team, appeared with incorrections in the preceding volume of Catalan Review accompanying the article by Cosme Aguiló. We apologize for the error and ask our readers to make a note of this correction.

THE EDITORS

12. Cot, còtil i altres derivats

cot
cotella
cotada
cotaina
is cotil
cotilar
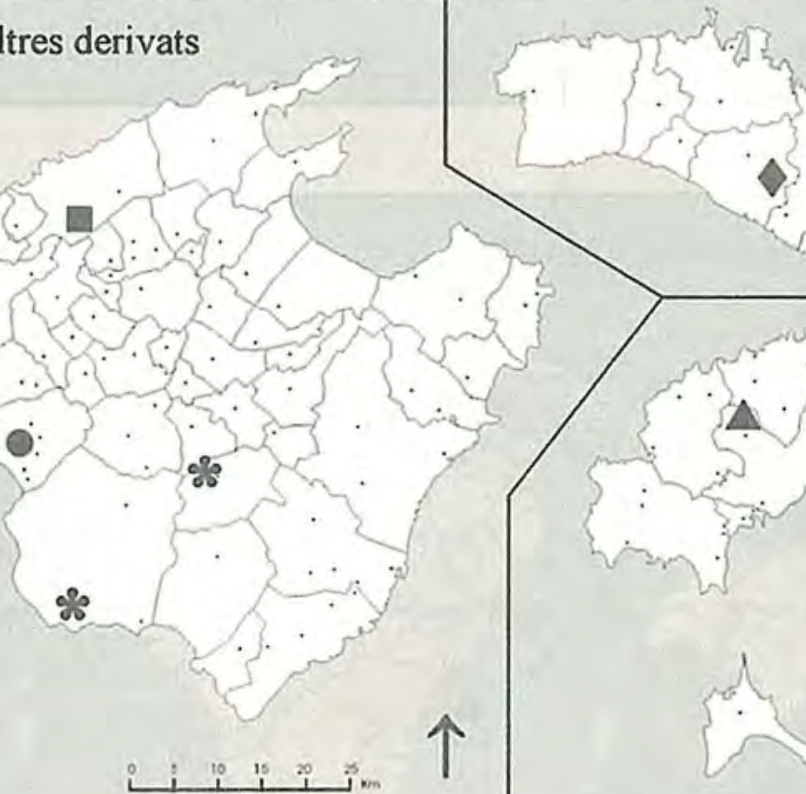

ish

in ,

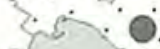




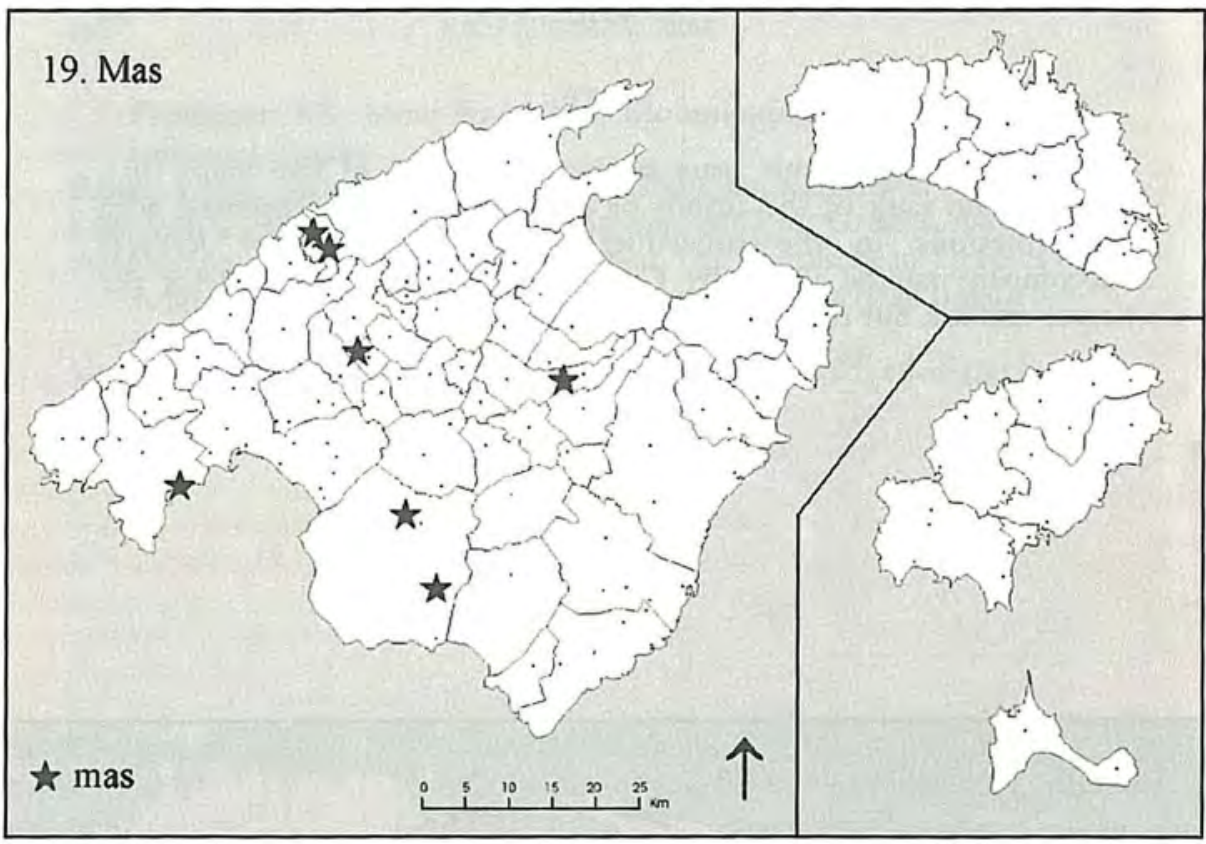

22. Pèlec, pelegó (peregó)

- pèlec

$\Delta$ peregó

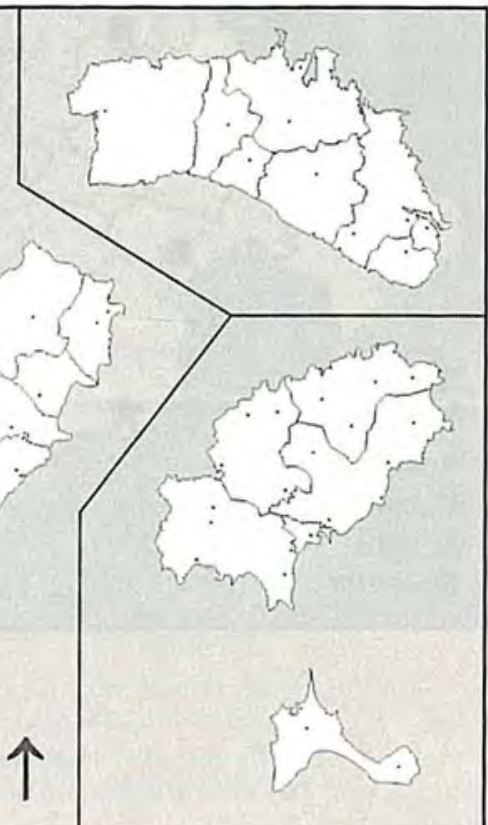


29. Torm, turmàs, turmassot

$\Delta$ torm

$\star$ turmàs

- turmassot
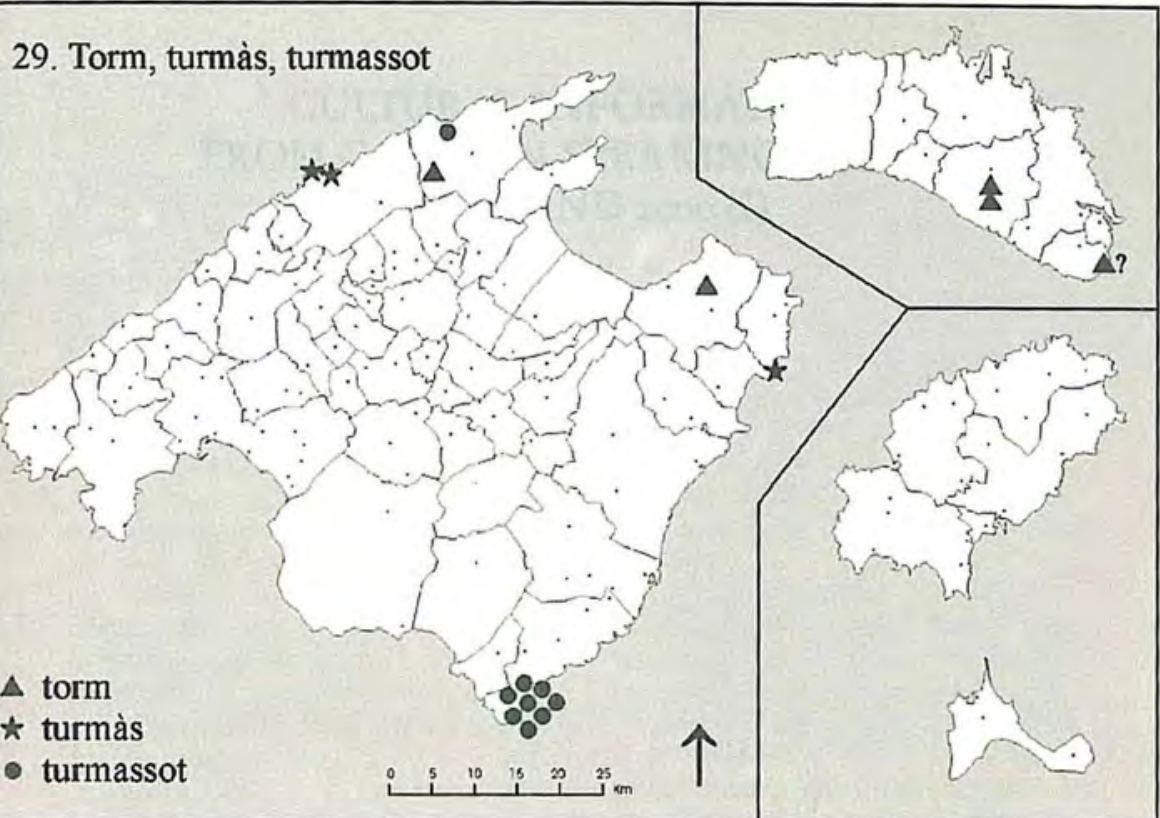

30. Tudòs, tudossa

- tudòs

$\Delta$ tudossa

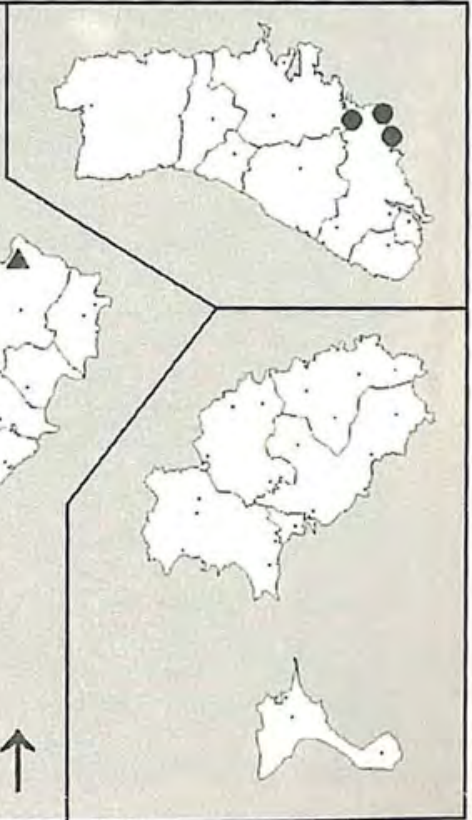

